\title{
GAME ELEMENTS FROM LITERATURE REVIEW OF GAMIFICATION IN HEALTHCARE CONTEXT
}

\author{
Sakchai Muangsrinoon $(\mathbb{D}$, Poonpong Boonbrahm $(\mathbb{D}$ \\ Walailak University (Thailand) \\ sakechai@juno.co.th,poonpong@gmail.com
}

Received September 2018

Accepted December 2018

\begin{abstract}
Gamification is a conceptual framework to apply game elements and techniques to improve the interesting process in non-game context. Gamification offers the motivation approach to motivate the player to handle the challenge tasks with game mechanics, game dynamics, and components. Nowadays, To discover the set of game elements and techniques from evaluating the existing related research is more opportunity for success in the exciting process. The core objective of this paper is to review the literature by using descriptive statistics of game elements with the review methodology. The reviewed literature was first coded author-centrally. After each paper was scrutinized for the analysis, the perspective was pivoted, and further analyses were conducted concept-centrally. A systematic review has been conducted that proves the wide variety of game elements, being retrieved a total of fifteen terms of game elements from twentytwo selected papers that were screened from a total of eighty-two documents. Only a few terms are used: points, feedback, levels, leaderboards, challenges, badges, avatars, competition, and cooperation. However, only some can be considered actual elements mechanics and that have not a similar abstraction level. Additionally, the authors examined the relationship between game elements and Self-Determination Theory (SDT): Competence, Autonomy, and Relatedness. The results indicated that a few terms of game elements were used: points, feedback, levels, leaderboards, challenges, badges, avatars, competition, and cooperation to explaine the relationship to SDT: Competence, Autonomy, and Relatedness. The results from this study will be used to design a gamified system in a healthcare context to promote physical activity.
\end{abstract}

Keywords - Gamification, Game elements, Review.

\section{To cite this article:}

Muangsrinoon, S., \& Boonbrahm, P. (2019). Game elements from literature review of gamification in healthcare context. Journal of Technology and Science Education, 9(1), 20-31. https://doi.org/10.3926/jotse.556

\section{Introduction}

Gamification is a conceptual framework to apply game elements and techniques to improve the interesting process in non-game context. Gamification offers the motivation approach to motivate the player to handle the challenge tasks with game mechanics, game dynamics, and components. Gamification can be applied in almost every area of knowledge. The most common areas of using gamification are followed: (a) Education, not only with applications or serious games but The form can also gamify teaching to 
increase academic performance. (b) Entertainment, gamification is used to improve user experience and ensure loyalty. (c) Health, there are many examples of gamified applications of telemedicine, and self-learning about diseases and to support the treatment and diagnosis. (d) Business environments, trying to improve the productivity and satisfaction of workers. Furthermore, (e) Marketing, where gamification can enhance the visualization of the product and becomes it nearer to the final consumer. There is still a gap in the definition and classification of game elements for some successful cases of gamified context; in this paper, The authors aim to identify the most common game elements and propose a term of game elements which related Self-Determination Theory that can be applied in the healthcare context. This paper is organized as follows: Section 2 is dedicated to exploring the related works related to gamification. Section 3 describes the performed systematic review of gamification for Healthcare. Section 4 presents the results of a Systematic Review of Gamification Research in Healthcare Context. Finally, Section 5 concludes the paper.

\section{Related Works}

\subsection{Gamification}

The most commonly define "Gamification" as the following statements: Deterding, Dixon, Khaled and Nacke (2011) described gamification as the use of game elements in non-game contexts. Bunchball.com (2010) defines gamification as the use of game mechanics in non-game activities to influence people's behavior. Zichermann and Cunningham (2011) describe gamification as the process of using game thinking and game mechanics to engage audiences and solve problems. If we want to simplify the definition of gamification, then we might think of it as the application of the essential elements that make games fun and engaging to things that typically are not considered a game. The main elements of gamification are followed: (a) Game elements: points, badges, leaderboards. (b) Game techniques: thinking as a computer game designer. and (c) Non-game contexts in other business domain such as education, entertainment, health, business, marketing.

Johnson, Deterding, Kuhn, Staneva, Stoyanov and Hides (2016) indicated that gamification could have a positive impact on health and wellbeing, Especially for health behaviors from the empirical evidence of the effects of gamification on health and well-being. Furthermore, The findings were evident for healthrelated behaviors but mixed for cognitive outcomes. While, Lumsden, Edwards, Lawrence, Coyle and Munafò (2016) concluded that working memory and general executive functions were most objective for both gamified assessment and training Additionally, Heterogeneous study designs and typically small sample sizes should be evaluated more. Furthermore, Dicheva, Dichev, Agre and Angelova (2015) indicated the research should be more on the empirical study to understand more how gamification can influence both extrinsic and intrinsic motivation to players. On the other hand, Clark, Tanner-Smith and Killingsworth (2016) indicated that digital games mainly enhanced player learning relative to non-game conditions, and value-added comparisons mainly indicated learning benefits associated with additional game designs. The results of using a random-effects meta-regression model with media comparisons explained the affordances of games for learning as well as the crucial role of design beyond the medium.

\subsection{Self-Determination Theory: SDT}

Self-Determination Theory (SDT) by Edward L. Deci and Richard M. Ryan (2000) states that the basic psychological needs that comprise Self-Determination as autonomy, competence, and Relatedness. (1) To meet the needs for self-determination. (2) To meet the needs of the ability. And (3) to meet the need for social interaction.

Forde, Mekler and Opwis (2015) studied the fundamental psychological mechanisms by comparing autonomy, competence, and intrinsic motivation between an informational and a controlling condition on gamification work and (2016) indicated that informational game elements such as points in form of scoreboards were ignored. Hiniker, Lee, Sobel and Choe (2017) indicated that the self-regulation in a non-digital setting can be applied effectively to children's use of technology by creating tools for preschoolers and parents to plan their device-based play-time. Huang (2017) applied the 
Self-Determination Theory in Human-Robot Interaction by using robotics tournaments as a test bed to seek evidence of people's need for autonomy, competence, relatedness to other humans, and intrinsic motivation and emotions toward interactions with robots. Noll, Razzak and Beecham (2017) studied the effect of global software development on motivation by finding the impact of misalignment between needed and actual autonomy.

\subsection{The Relationship Between Game Elements (Gamification) and Self-Determination Theory}

\begin{tabular}{|l|l|c|c|c|}
\hline Game element & Definition & Autonomy & Competence & Relatedness \\
\hline Achievements & Completing goals. & & $\mathrm{x}$ & $\mathrm{x}$ \\
\hline Avatars & Visual of a player's character. & & $\mathrm{x}$ & \\
\hline Badges & Visual of achievements. & & $\mathrm{x}$ & \\
\hline Boss Fights & Special challenges at the end of a level. & & $\mathrm{x}$ \\
\hline Collections & Sets of accumulated items or badges. & & $\mathrm{x}$ & \\
\hline Combat & Defined challenge. & $\mathrm{x}$ & $\mathrm{x}$ \\
\hline Content Unblocking & Privilege for players. & & $\mathrm{x}$ \\
\hline Gifting & Sharing resources with others. & $\mathrm{x}$ & $\mathrm{x}$ \\
\hline Leaderboards & Visual displays of social comparison. & $\mathrm{x}$ & $\mathrm{x}$ \\
\hline Levels & The player's progressive. & $\mathrm{x}$ & $\mathrm{x}$ \\
\hline Points & The virtual rewards against the player effort. & & $\mathrm{x}$ \\
\hline Quests & Predefined challenges. & & $\mathrm{x}$ & $\mathrm{x}$ \\
\hline Social Graph & Representation of players' social network. & & $\mathrm{x}$ & $\mathrm{x}$ \\
\hline Teams & Group of players for a common goal. & & $\mathrm{x}$ \\
\hline Virtual Goods & Game assets. & $\mathrm{x}$ & & $\mathrm{x}$ \\
\hline
\end{tabular}

Table 1. The relationship between game elements (Components) and Self-Determination Theory (Werbach \& Hunter, 2012)

\section{Method}

\subsection{Research Questions}

This research question was elaborated to meet the purpose of the study.

\section{RQ: Which game elements are being implemented in the research of gamification?}

Thus, the authors conducted a systematic review to answer the formulated RQ. The flow to perform the systematic the review was the following: First, to determine the electronic database(s) were exploring to the objectives of this study. Second, To identify the target keywords and define the searching string. Third, to determine inclusion/exclusion criteria, i.e., the mandatory eligibility factors to include documents in the current study. Forth, to screen those documents that previously accomplished the eligibility factors using the title and abstract. Fifth, Based on the content of the papers, to select those documents that provide information about game elements; Sixth, to determine the metrics to characterize them and deliver the results of this systematic review.

\subsection{Data Collection}

The searched electronic databases were follow: ACM (Association for Computing Machinery), IEEE (Institute of Electrical and Electronics Engineers), and Science Direct. The authors used the following criteria: (1) use the search terms that related term of gamification, gamified, and gamifying: ("gamif*"). (2) use the inclusion criteria: name fulfill one of the search strings; journal, conference; Publication during 2013-2017; and Paper was written in English, and exclusion criteria: Papers that do not relate to gamification; Papers which are available only abstract; Workshop's paper; Gamification which was implemented in non-health context; Duplicated study.Furthermore, the authors had extracted data from 
the title, abstract, and keywords in the first step, and from introduction, methods, and conclusions in the last step.

\subsection{Data Analysis}

Coding of papers

Coding of game elements: game dynamics, game mechanics, and components.

Coding of methods: study design, sampling, data collection, data analysis, and results and conclusions.

Coding of the basic psychological need of SDT: autonomy, competence, and relatedness.

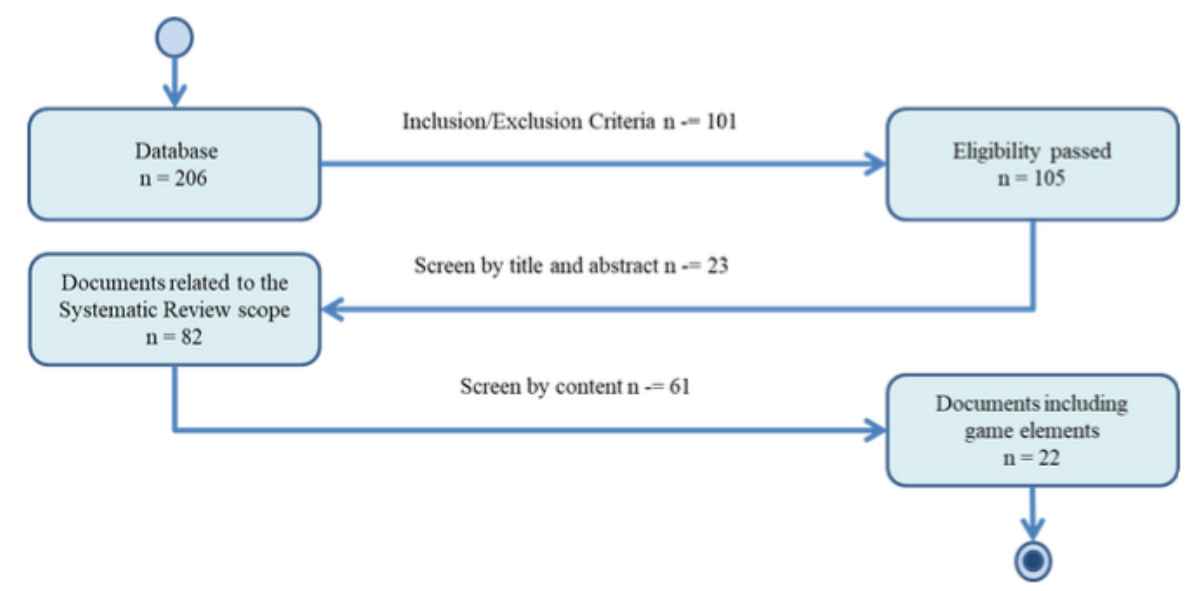

Figure 1. Flow diagram of the systematic review process

\section{Results}

Table 2 shows the summary of the extract data from the selected papers: the published year, authors, the problem points, proposal, type of studies design, and performance evaluation.

\begin{tabular}{|c|l|l|l|l|l|}
\hline Year & \multicolumn{1}{|c|}{ Authors } & \multicolumn{1}{|c|}{$\begin{array}{c}\text { Problem } \\
\text { Points }\end{array}$} & \multicolumn{1}{c|}{$\begin{array}{c}\text { Proposal } \\
\text { Type of Studies } \\
\text { Design }\end{array}$} & \multicolumn{1}{c|}{$\begin{array}{c}\text { Performance } \\
\text { Evaluation }\end{array}$} \\
\hline 2013 & $\begin{array}{l}\text { Giannakis, } \\
\text { Chorianopoulos } \\
\text { and Jaccheri }\end{array}$ & $\begin{array}{l}\text { To study } \\
\text { relationship } \\
\text { between real-time } \\
\text { feedback and } \\
\text { workouts level. }\end{array}$ & $\begin{array}{l}\text { The authors } \\
\text { employed a four- } \\
\text { week long } \\
\text { experiment with five } \\
\text { users who were } \\
\text { asked to perform } \\
\text { multiple workouts } \\
\text { with two levels of } \\
\text { gamification. }\end{array}$ & $\begin{array}{l}\text { The quasi } \\
\text { experimental of } \\
\text { workouts logs, such } \\
\text { as time, distance, } \\
\text { speed, calories, } \\
\text { elevation, and show } \\
\text { of athlete's route } \\
\text { on Google Maps, } \\
\text { and post-exercise } \\
\text { questionnaires. }\end{array}$ & $\begin{array}{l}\text { Augmented feedback } \\
\text { from mobile self- } \\
\text { tracking devices can } \\
\text { promote working out, } \\
\text { but there is also a trade- } \\
\text { off between increased } \\
\text { anxiety and } \\
\text { disorientation. However, } \\
\text { sports tracking software } \\
\text { should be considered for } \\
\text { visualization real-time } \\
\text { feedbacks. }\end{array}$ \\
\hline 2013 & $\begin{array}{l}\text { Vella, Johnson } \\
\text { and Hides }\end{array}$ & $\begin{array}{l}\text { To investigate how } \\
\text { the gameplay }\end{array}$ & $\begin{array}{l}\text { The authors present } \\
\text { a hierarchical } \\
\text { multiple regression } \\
\text { to determine if, } \\
\text { controlling for age } \\
\text { and gender, current } \\
\text { gameplay choices } \\
\text { and play experience } \\
\text { predicted current } \\
\text { wellbeing. }\end{array}$ & $\begin{array}{l}\text { An online survey } \\
\text { with four hundred } \\
\text { and twenty-nine } \\
\text { participants on } \\
\text { gameplay. }\end{array}$ & $\begin{array}{l}\text { Results indicated that } \\
\text { age, social play, } \\
\text { relatedness during } \\
\text { gameplay and flow were } \\
\text { positively associated } \\
\text { with player wellbeing. }\end{array}$ \\
\hline
\end{tabular}




\begin{tabular}{|c|c|c|c|c|c|}
\hline Year & Authors & $\begin{array}{l}\text { Problem } \\
\text { Points }\end{array}$ & Proposal & $\begin{array}{c}\text { Type of Studies } \\
\text { Design }\end{array}$ & $\begin{array}{c}\text { Performance } \\
\text { Evaluation }\end{array}$ \\
\hline 2014 & $\begin{array}{l}\text { Chen, King and } \\
\text { Hekkler }\end{array}$ & $\begin{array}{l}\text { To study the } \\
\text { potential impact of } \\
\text { focusing on } \\
\text { "healthifying" } \\
\text { exergames as } \\
\text { opposed to } \\
\text { gamifying health } \\
\text { behaviors. }\end{array}$ & $\begin{array}{l}\text { The authors present } \\
\text { an experimental } \\
\text { study where they } \\
\text { vary the framing of } \\
\text { intention and } \\
\text { feedback to explore } \\
\text { their unique and } \\
\text { interactive impacts } \\
\text { on perceived } \\
\text { exertion, objectively } \\
\text { measured energy } \\
\text { expenditure, affect, } \\
\text { and duration of } \\
\text { usage in a single } \\
\text { session. }\end{array}$ & $\begin{array}{l}\text { Experimental study } \\
\text { and semi- } \\
\text { structured } \\
\text { interviews }\end{array}$ & $\begin{array}{l}\text { The authors concluded } \\
\text { with a discussion on the } \\
\text { potential impact of } \\
\text { focusing on both game } \\
\text { and exercise. }\end{array}$ \\
\hline 2014 & Chen and $\mathrm{Pu}$ & $\begin{array}{l}\text { To investigate the } \\
\text { aspect of social } \\
\text { interaction and } \\
\text { how users play } \\
\text { games together in a } \\
\text { group remains an } \\
\text { open subject. }\end{array}$ & $\begin{array}{l}\text { The authors } \\
\text { developed a mobile } \\
\text { game to understand } \\
\text { how users interact } \\
\text { in different group } \\
\text { gamification } \\
\text { settings: } \\
\text { competition, } \\
\text { cooperation, or } \\
\text { hybrid. }\end{array}$ & Experimental study & $\begin{array}{l}\text { Results show that users } \\
\text { significantly enhanced } \\
\text { physical activities using a } \\
\text { mobile game compared } \\
\text { with when they exercised } \\
\text { alone by up to } 15 \% \text {. } \\
\text { Among the group } \\
\text { settings, cooperation } \\
(21 \% \text { increase) and } \\
\text { hybrid (18\% increase) } \\
\text { outperformed } \\
\text { competition ( } 8 \% \\
\text { increase). }\end{array}$ \\
\hline 2014 & $\begin{array}{l}\text { Nacke, Klauser } \\
\text { and Prescod }\end{array}$ & $\begin{array}{l}\text { To track social } \\
\text { behavior change in } \\
\text { social network } \\
\text { games. }\end{array}$ & $\begin{array}{l}\text { The authors } \\
\text { developed social } \\
\text { player metrics in a } \\
\text { quantitative study } \\
\text { of player behavior } \\
\text { in a social health } \\
\text { game. }\end{array}$ & Correlational study & $\begin{array}{l}\text { The results support that } \\
\text { social interactions game } \\
\text { mechanics can motivate } \\
\text { players to solve more } \\
\text { missions, to fulfill more } \\
\text { healthy goals and to play } \\
\text { the game longer. }\end{array}$ \\
\hline 2014 & $\begin{array}{l}\text { Vourvopoulos, } \\
\text { Faria, Ponnam } \\
\text { and Badia }\end{array}$ & $\begin{array}{l}\text { To design of } \\
\text { personalized tools } \\
\text { that can be used } \\
\text { intensively by } \\
\text { patients and } \\
\text { therapists in } \\
\text { clinical or at home } \\
\text { environments. }\end{array}$ & $\begin{array}{l}\text { The authors present } \\
\text { the design, } \\
\text { implementation, } \\
\text { and validation of } \\
\text { RehabCity, an } \\
\text { online game } \\
\text { designed for the } \\
\text { rehabilitation of } \\
\text { cognitive deficits } \\
\text { through a gamified } \\
\text { approach to } \\
\text { activities of daily } \\
\text { living (ADLs) }\end{array}$ & Correlational study & $\begin{array}{l}\text { These findings suggest } \\
\text { that RehabCity is a valid } \\
\text { tool for the quantitative } \\
\text { assessment of patients } \\
\text { with cognitive deficits } \\
\text { derived from a brain } \\
\text { lesion. }\end{array}$ \\
\hline 2015 & Saksono & $\begin{array}{l}\text { How can } \\
\text { exergames be } \\
\text { designed to avoid } \\
\text { potential negative } \\
\text { consequences of } \\
\text { competition? }\end{array}$ & $\begin{array}{l}\text { The authors } \\
\text { designed Spaceship } \\
\text { Launch, an } \\
\text { exergame for } \\
\text { parents and kids in } \\
\text { lower-income } \\
\text { neighborhoods, } \\
\text { where obesity is } \\
\text { most prevalent. }\end{array}$ & $\begin{array}{l}\text { Interview the focus } \\
\text { group }\end{array}$ & $\begin{array}{l}\text { The findings highlight } \\
\text { the impact of an } \\
\text { exergame on physical } \\
\text { activity intentions, and } \\
\text { how parental } \\
\text { preferences for the in- } \\
\text { game competition were } \\
\text { aligned with the } \\
\text { psychological needs of } \\
\text { relatedness and } \\
\text { competence. }\end{array}$ \\
\hline
\end{tabular}




\begin{tabular}{|c|c|c|c|c|c|}
\hline Year & Authors & $\begin{array}{c}\text { Problem } \\
\text { Points }\end{array}$ & Proposal & $\begin{array}{c}\text { Type of Studies } \\
\text { Design }\end{array}$ & $\begin{array}{c}\text { Performance } \\
\text { Evaluation }\end{array}$ \\
\hline 2016 & $\begin{array}{l}\text { Geelan, Zulkifly, } \\
\text { Smith, } \\
\text { Cauchi-Saunders } \\
\text {, de Salas and } \\
\text { Lewis }\end{array}$ & $\begin{array}{l}\text { The problem of } \\
\text { lack of motivation } \\
\text { for and } \\
\text { engagement in } \\
\text { exercise is well } \\
\text { known, and so } \\
\text { identifying } \\
\text { techniques to } \\
\text { improve } \\
\text { engagement in } \\
\text { exercise activities is } \\
\text { worthy of } \\
\text { investigation. }\end{array}$ & $\begin{array}{l}\text { The author's reports } \\
\text { on an initiative } \\
\text { designed to increase } \\
\text { both the duration } \\
\text { of exercise activity } \\
\text { and the intensity of } \\
\text { exercise activity, } \\
\text { through a gamified } \\
\text { exercise solution. }\end{array}$ & $\begin{array}{l}\text { Experimental study } \\
\text { and Survey, } 24 \\
\text { participants ( } 9 \text { male } \\
\text { and } 15 \text { female), } \\
\text { aged between } 18 \\
\text { and } 67 \text { (mean 31.5), } \\
\text { and a mean Body } \\
\text { Mass Index of } 27.1 \\
\text { (SD 3.93). }\end{array}$ & $\begin{array}{l}\text { Preliminary results } \\
\text { indicate that augmenting } \\
\text { traditional exercise } \\
\text { equipment with gamified } \\
\text { elements can increase } \\
\text { the time spent exercising } \\
\text { when compared to } \\
\text { non-gamified exercise } \\
\text { equipment. }\end{array}$ \\
\hline 2016 & $\begin{array}{l}\text { Kosoris, Liu, } \\
\text { Phelps, Medda, } \\
\text { Swanson, Gore } \\
\text { et al. }\end{array}$ & $\begin{array}{l}\text { To develop } \\
\text { gamification of the } \\
\text { health assessment. }\end{array}$ & $\begin{array}{l}\text { The authors } \\
\text { proposed the 2D } \\
\text { Heads-Up Display } \\
\text { based gamified } \\
\text { health assessment; } \\
\text { the entire project } \\
\text { was translated to } \\
\text { 3D Virtual Reality } \\
\text { under significant } \\
\text { constraints. }\end{array}$ & & $\begin{array}{l}\text { Some aspects of user } \\
\text { response to immersion } \\
\text { required significant } \\
\text { changes to gameplay } \\
\text { mechanics. Iterative, } \\
\text { collaborative } \\
\text { development was critical } \\
\text { to increasing } \\
\text { gamification while } \\
\text { maintaining a useful } \\
\text { assessment tool. } \\
\end{array}$ \\
\hline 2016 & $\begin{array}{l}\text { Pablo, Carina, } \\
\text { Jaime and Silvia }\end{array}$ & $\begin{array}{l}\text { To improve } \\
\text { phonological } \\
\text { awareness in } \\
\text { children with } \\
\text { dyslexia by using a } \\
\text { computer game } \\
\text { designed } \\
\text { specifically for this } \\
\text { study and applying } \\
\text { it as an educational } \\
\text { resource in a } \\
\text { formal-inclusive } \\
\text { educational } \\
\text { environment. }\end{array}$ & $\begin{array}{l}\text { The authors used a } \\
\text { quasi-experimental } \\
\text { scientific method } \\
\text { They apply the } \\
\text { T.E.D.E. test with } \\
\text { the pre-test and } \\
\text { post-test } \\
\text { methodology for } \\
\text { the whole sample. }\end{array}$ & $\begin{array}{l}\text { A quasi- } \\
\text { experimental } \\
\text { scientific method } \\
\text { with a sample of } \\
12 \text { children, aged } \\
\text { between } 6 \text { to } 12 \\
\text { years, divided into } \\
\text { two groups: } \\
\text { experimental (six) } \\
\text { and control (six) } \\
\text { with Pre-test Post- } \\
\text { test. }\end{array}$ & $\begin{array}{l}\text { The research shows } \\
\text { significant differences, } \\
\text { with a } 95 \% \text { confidence } \\
\text { level, in the experimental } \\
\text { population after } \\
\text { applying the gaming } \\
\text { strategies. These results } \\
\text { exceed those of } \\
\text { previous studies with } \\
\text { digital gaming resources } \\
\text { and pave the way for the } \\
\text { second stage of research } \\
\text { with a broader } \\
\text { population1. }\end{array}$ \\
\hline 2016 & $\begin{array}{l}\text { Zhao, Etemad, } \\
\text { Whitehead and } \\
\text { Arya }\end{array}$ & $\begin{array}{l}\text { To investigate the } \\
\text { motivational } \\
\text { effects of using } \\
\text { sensor-based } \\
\text { games to promote } \\
\text { daily exercise, as } \\
\text { well as how } \\
\text { different methods } \\
\text { of releasing the } \\
\text { application and its } \\
\text { updated features } \\
\text { may affect user's } \\
\text { enthusiasm and the } \\
\text { game's life-cycle. }\end{array}$ & $\begin{array}{l}\text { The authors report } \\
\text { the early results of a } \\
\text { long-term (70-day) } \\
\text { study of using } \\
\text { wearable activity } \\
\text { trackers and } \\
\text { gamification to } \\
\text { promote exercise } \\
\text { and being more } \\
\text { active. }\end{array}$ & $\begin{array}{l}\text { Experimental study } \\
\text { and pre and post- } \\
\text { study } \\
\text { questionnaires }\end{array}$ & $\begin{array}{l}\text { The initial results seem } \\
\text { to support the notion of } \\
\text { using the gradual } \\
\text { addition of features or } \\
\text { changes as means of } \\
\text { sustaining the } \\
\text { participants' interest and } \\
\text { usage. }\end{array}$ \\
\hline 2017 & $\begin{array}{l}\text { Goh, Tan and } \\
\text { Lee }\end{array}$ & $\begin{array}{l}\text { To expand on the } \\
\text { development of a } \\
\text { custom } \\
\text { measurement } \\
\text { device for heel } \\
\text { raise physiotherapy } \\
\text { that uses the } \\
\text { concept of } \\
\text { gamification to } \\
\text { promote and } \\
\text { motivate users to } \\
\text { participate in heel } \\
\text { raise exercises }\end{array}$ & $\begin{array}{l}\text { The authors } \\
\text { proposed a game } \\
\text { where players } \\
\text { control an avatar to } \\
\text { jump onto } \\
\text { platforms by } \\
\text { executing heel } \\
\text { raises. }\end{array}$ & $\begin{array}{l}\text { Experimental study } \\
\text { and interviews }\end{array}$ & $\begin{array}{l}\text { In preliminary studies, } \\
\text { the game has been } \\
\text { evaluated to have some } \\
\text { positive effects on older } \\
\text { adults, such as increased } \\
\text { motivation and the } \\
\text { tendency to perform } \\
\text { more repetitions of the } \\
\text { exercise. }\end{array}$ \\
\hline
\end{tabular}




\begin{tabular}{|c|c|c|c|c|c|}
\hline Year & Authors & $\begin{array}{c}\text { Problem } \\
\text { Points }\end{array}$ & Proposal & $\begin{array}{l}\text { Type of Studies } \\
\text { Design }\end{array}$ & $\begin{array}{c}\text { Performance } \\
\text { Evaluation }\end{array}$ \\
\hline $2017 \mathrm{a}$ & Herpich et al. & $\begin{array}{l}\text { To promote a } \\
\text { healthy lifestyle and } \\
\text { to increase the } \\
\text { well-being of older } \\
\text { adults, they have } \\
\text { extended a digital } \\
\text { picture frame that } \\
\text { interleaves a } \\
\text { picture display } \\
\text { mode with a } \\
\text { recommended } \\
\text { mode. }\end{array}$ & $\begin{array}{l}\text { The authors } \\
\text { investigate in how } \\
\text { far rewarding } \\
\text { schemes as known } \\
\text { from computer } \\
\text { games could be } \\
\text { deployed to increase } \\
\text { user appreciation of } \\
\text { the CARE system. }\end{array}$ & Experimental study & $\begin{array}{l}\text { They draw conclusions } \\
\text { that will guide their work } \\
\text { towards a gamified } \\
\text { version of CARE. }\end{array}$ \\
\hline $2017 b$ & Herpich et al. & $\begin{array}{l}\text { To promote a } \\
\text { healthy lifestyle and } \\
\text { to increase the } \\
\text { well-being of older } \\
\text { adults. }\end{array}$ & $\begin{array}{l}\text { The authors } \\
\text { investigate the use } \\
\text { of gamification as a } \\
\text { means to increase } \\
\text { user appreciation of } \\
\text { the CARE system. } \\
\text { To this end, we } \\
\text { arranged two co- } \\
\text { design workshops } \\
\text { with peer-groups of } \\
\text { senior citizens. }\end{array}$ & $\begin{array}{l}\text { Predefined } \\
\text { questions for semi- } \\
\text { structured } \\
\text { interviews }\end{array}$ & $\begin{array}{l}\text { They draw conclusions } \\
\text { that will guide their work } \\
\text { towards a gamified } \\
\text { version of CARE. }\end{array}$ \\
\hline 2017 & $\begin{array}{l}\text { Kappen, } \\
\text { Mirza-Babaei, } \\
\text { and Nacke }\end{array}$ & $\begin{array}{l}\text { There are no } \\
\text { previous } \\
\text { comparisons of } \\
\text { either the } \\
\text { motivation to } \\
\text { participate in } \\
\text { physical activity } \\
\text { (PA) or } \\
\text { motivational } \\
\text { affordances that } \\
\text { facilitate Physical } \\
\text { Activity (PA) in } \\
\text { different age } \\
\text { groups. }\end{array}$ & $\begin{array}{l}\text { The authors } \\
\text { conducted an online } \\
\text { survey to explore } \\
\text { motivational } \\
\text { affordances and PA } \\
\text { technology } \\
\text { preferences in four } \\
\text { age groups. }\end{array}$ & $\begin{array}{l}\text { an online survey } \\
\text { with } 150 \\
\text { participants using } \\
\text { the Exercise } \\
\text { Motivations } \\
\text { Inventory-2 scale } \\
\text { (EMI-2) }\end{array}$ & $\begin{array}{l}\text { The results suggest } \\
\text { health-related pressures } \\
\text { are significant } \\
\text { motivations for PA in } \\
\text { different age groups. } \\
\text { Additionally, a content } \\
\text { analysis of preferences } \\
\text { allowed us to distinguish } \\
\text { between gamified } \\
\text { motivational affordances } \\
\text { and feedback elements. }\end{array}$ \\
\hline 2017 & $\begin{array}{l}\text { Litovuo, } \\
\text { Makkonen, } \\
\text { Aarikka- } \\
\text { Stenroos, } \\
\text { Luhtala and } \\
\text { Makinen }\end{array}$ & $\begin{array}{l}\text { To explore the } \\
\text { medical game } \\
\text { ecosystem and } \\
\text { reveals the } \\
\text { reciprocal value } \\
\text { propositions of the } \\
\text { relevant actors of } \\
\text { medical game } \\
\text { ecosystems, as well } \\
\text { as barriers that may } \\
\text { be complicating or } \\
\text { hindering } \\
\text { realization of the } \\
\text { value propositions. }\end{array}$ & $\begin{array}{l}\text { The authors present } \\
12 \text { actor groups, } \\
\text { their value } \\
\text { propositions, and } \\
\text { the barriers between } \\
\text { the actors. }\end{array}$ & $\begin{array}{l}\text { thematic interviews } \\
\text { with } 24 \\
\text { interviewees }\end{array}$ & $\begin{array}{l}\text { The result gives a } \\
\text { comprehensive view of } \\
\text { the actual medical game } \\
\text { ecosystem that is needed } \\
\text { to utilize the full } \\
\text { potential of gamification } \\
\text { and serious games in the } \\
\text { healthcare sector. }\end{array}$ \\
\hline 2017 & $\begin{array}{l}\text { Mollee, } \\
\text { Middelweerd, } \\
\text { Kurvers and } \\
\text { Klein }\end{array}$ & $\begin{array}{l}\text { To investigate the } \\
\text { current landscape } \\
\text { of smartphone } \\
\text { apps that promote } \\
\text { physical activity for } \\
\text { healthy adults. }\end{array}$ & $\begin{array}{l}\text { The authors present } \\
\text { a framework to rate } \\
\text { the extent to which } \\
\text { such apps } \\
\text { incorporate } \\
\text { technological } \\
\text { features. }\end{array}$ & Correlational study & $\begin{array}{l}\text { The results indicate that } \\
\text { apps can be improved } \\
\text { substantially regarding } \\
\text { their utilization of the } \\
\text { possibilities that current } \\
\text { mobile technology } \\
\text { offers. }\end{array}$ \\
\hline
\end{tabular}




\begin{tabular}{|c|c|c|c|c|c|}
\hline Year & Authors & $\begin{array}{l}\text { Problem } \\
\text { Points }\end{array}$ & Proposal & $\begin{array}{c}\text { Type of Studies } \\
\text { Design }\end{array}$ & $\begin{array}{l}\text { Performance } \\
\text { Evaluation }\end{array}$ \\
\hline 2017 & $\begin{array}{l}\text { Orji, Nacke and } \\
\text { Marco }\end{array}$ & $\begin{array}{l}\text { To prove that the } \\
\text { simple game-based } \\
\text { efficient system } \\
\text { can increase people } \\
\text { efficacy. }\end{array}$ & $\begin{array}{l}\text { The authors } \\
\text { conducted a large- } \\
\text { scale study of } 660 \\
\text { participants to } \\
\text { investigate how } \\
\text { different } \\
\text { personalities } \\
\text { respond to various } \\
\text { persuasive strategies } \\
\text { that are used in } \\
\text { active health games } \\
\text { and gamified } \\
\text { systems. }\end{array}$ & Correlational study & $\begin{array}{l}\text { The results reveal that } \\
\text { people's personality } \\
\text { traits play a significant } \\
\text { role in the perceived } \\
\text { persuasiveness of } \\
\text { different strategies. } \\
\text { Conscientious people } \\
\text { tend to be motivated by } \\
\text { goal setting, simulation, } \\
\text { self-monitoring, and } \\
\text { feedback; people who } \\
\text { are more open to } \\
\text { experience are more } \\
\text { likely to be demotivated } \\
\text { by rewards, competition, } \\
\text { comparison, and } \\
\text { cooperation. }\end{array}$ \\
\hline 2017 & $\begin{array}{l}\text { Shameli, } \\
\text { Althoff, Saberi } \\
\text { and Leskovec }\end{array}$ & $\begin{array}{l}\text { To study how } \\
\text { competitions affect } \\
\text { physical activity. }\end{array}$ & $\begin{array}{l}\text { The authors analyze } \\
\text { nearly } 2,500 \\
\text { physical activity } \\
\text { competitions over a } \\
\text { period of one year } \\
\text { capturing more than } \\
800,000 \text { person days } \\
\text { of activity tracking. }\end{array}$ & Correlational study & $\begin{array}{l}\text { There are significant } \\
\text { increases in activity for } \\
\text { both men and women } \\
\text { across all ages, and } \\
\text { weight status, and even } \\
\text { for users that were } \\
\text { previously relatively } \\
\text { inactive. The authors } \\
\text { find that the } \\
\text { composition of } \\
\text { participants dramatically } \\
\text { affects the dynamics of } \\
\text { the game. }\end{array}$ \\
\hline 2017 & $\begin{array}{l}\text { Tondello, Orji } \\
\text { and Nacke }\end{array}$ & $\begin{array}{l}\text { Lacking a general } \\
\text { framework for } \\
\text { building } \\
\text { personalized } \\
\text { gameful } \\
\text { applications. }\end{array}$ & $\begin{array}{l}\text { The authors present } \\
\text { a novel general } \\
\text { framework for } \\
\text { personalized } \\
\text { gameful } \\
\text { applications using } \\
\text { recommender } \\
\text { systems. }\end{array}$ & & $\begin{array}{l}\text { This framework } \\
\text { contributes to } \\
\text { understanding and } \\
\text { building efficient } \\
\text { persuasive and gameful } \\
\text { applications by } \\
\text { describing the different } \\
\text { building blocks of a } \\
\text { recommender system in } \\
\text { a personalized } \\
\text { gamification context. }\end{array}$ \\
\hline 2017 & $\begin{array}{l}\text { Tong, Gupta, } \\
\text { Lo, Choo, } \\
\text { Gomala and } \\
\text { Shaw }\end{array}$ & $\begin{array}{l}\text { Does Pokémon Go } \\
\text { trigger more active } \\
\text { levels of } \\
\text { sustainable Physical } \\
\text { Activity (PA) or } \\
\text { behavior changes } \\
\text { for health benefits? }\end{array}$ & $\begin{array}{l}\text { The authors } \\
\text { presented a critical } \\
\text { analysis of } \\
\text { Pokémon Go } \\
\text { players' experience } \\
\text { from an online } \\
\text { survey filled in by } \\
32 \text { participants. }\end{array}$ & $\begin{array}{l}\text { The Online Survey. } \\
\text { The goal of this } \\
\text { survey is to get a } \\
\text { glimpse of } \\
\text { Pokémon Go } \\
\text { players' motivation, } \\
\text { their play patterns } \\
\text { and experience, and } \\
\text { an understanding } \\
\text { of their self- } \\
\text { reported behavior } \\
\text { changes and } \\
\text { concerns. }\end{array}$ & $\begin{array}{l}\text { The results revealed } \\
\text { both negative and } \\
\text { positive outcomes of the } \\
\text { gamification approach } \\
\text { Pokémon Go adopted. }\end{array}$ \\
\hline
\end{tabular}

Table 2. Summary of the extract data from the selected papers 


\subsection{Game Elements Used in Papers}

Table 3 shows that game elements were used in the papers: seven for points, four for levels and leaderboards, three for badges, two for avatars, and one for quests, social graph, and virtual goods, while the rest components were not used. In Table 1. The authors can prepare a dataset as follows.

\begin{tabular}{|c|l|l|}
\hline No & \multicolumn{1}{|c|}{ Game element } & \multicolumn{1}{|c|}{ Papers } \\
\hline 1 & Achievements & n/a \\
\hline 2 & Avatars & Goh et al. (2017), Chen et al. (2014) \\
\hline 3 & Badges & Chen and Pu (2014), Herpich et al. (2017a), Herpich et al. (2017b), Chen et al. (2014) \\
\hline 4 & Boss Fights & n/a \\
\hline 5 & Collections & n/a \\
\hline 6 & Combat & n/a \\
\hline 7 & Content Unblocking & n/a \\
\hline 8 & Gifting & n/a \\
\hline 9 & Leaderboards & Nacke et al. (2014), Saksono (2015), Zhao et al. (2016), Chen et al (2014) \\
\hline 10 & Levels & Nacke et al. (2014), Saksono (2015), Zhao et al. (2016), Chen et al (2014) \\
\hline 11 & Points & $\begin{array}{l}\text { Giannakis et al. (2013), Chen and Pu (2014), Saksono (2015), Zhao et al (2016), } \\
\text { Hiniker et al. (2017), Dicheva et al. (2015), Clark et al. (2016) }\end{array}$ \\
\hline 12 & Quests & Nacke et al. (2014) \\
\hline 13 & Social Graph & Nacke et al. (2014) \\
\hline 14 & Teams & n/a \\
\hline 15 & Virtual Goods & Herpich et al. (2017a), Herpich et al. (2017b) \\
\hline
\end{tabular}

Table 3. Game elements: Components used in papers (Werbach \& Hunter, 2012)

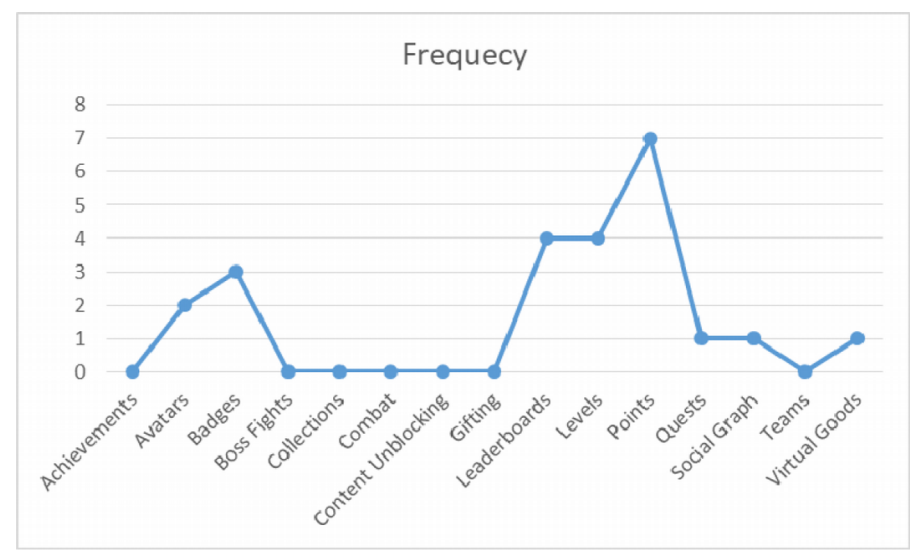

Figure 2. Frequency of game elements (Components)

\section{Conclusion}

In this study, the authors have evidenced the broad interpretation of game elements, including a different terminology to define the way in which gamification is developed. Using Werbach and Hunter (2012) as the reference, the authors propose the use of game elements as aseptic but concrete terminology or technique when the authors need to remark the proved effectiveness of game elements. A systematic review has been conducted that proves the wide variety of game elements, being retrieved a total of fifteen terms of game elements from twenty-two selected papers that were screened from a total of eighty-two documents. Only a few terms are used: points, feedback, levels, leaderboards, challenges, badges, avatars, competition, and cooperation. However, only some can be considered actual elements mechanics and that have not a similar abstraction level. 


\section{Declaration of Conflicting Interests}

The authors declared no potential conflicts of interest with respect to the research, authorship, and/or publication of this article.

\section{Funding}

The authors received no financial support for the research, authorship, and/or publication of this article.

\section{References}

Bunchball.com (2010). Gamification 101: An Introduction to the Use of Game Dynamics to Influence Behavior. http://www.bunchball.com/gamification/gamification101.pdf

Chen, F., King, A.C., \& Hekkler, E.B. (2014). “Healthifying” Exergames: Improving Health Outcomes through Intentional Priming. In Proceedings of the SIGCHI Conference on Human Factors in Computing Systems (CHI'14) (1855-1864). ACM, New York, NY, USA. https://doi.org/10.1145/2556288.2557246

Chen, Y., and Pu, P. (2014). HealthyTogether: Exploring Social Incentives for Mobile Fitness Applications. In Proceedings of the Second International Symposium of Chinese CHI (Chinese CHI'14) (25-34). ACM, New York, NY, USA. http://doi.acm.org/10.1145/2592235.2592240

Clark, D.B., Tanner-Smith, E.E., \& Killingsworth, S.S. (2016). Digital Games, Design, and Learning: A Systematic Review and Meta-Analysis. Review of Educational Research March, 86(1), 79-122. http://doi.org/10.3102/0034654315582065

Deterding, S., Dixon, D., Khaled, R., \& Nacke, L. (2011), From Game Design Elements to Gamefulness: Defining “Gamification”. In MindTrek'11. Tampere, Finland. ACM.

Dicheva, D., Dichev, C., Agre, G. \& Angelova, G. (2015). Gamification in Education: A Systematic Mapping Study. Educational Technology \& Society, 18(3).

Forde, S.F., Mekler, E.D., \& Opwis, K. (2015). Informational vs. Controlling Gamification: A Study Design. In Proceedings of the 2015 Annual Symposium on Computer-Human Interaction in Play (CHI PLAY'15) (517-522). ACM, New York, NY, USA. https:// doi.org/10.1145/2793107.2810297

Geelan, B., Zulkifly, A., Smith, A., Cauchi-Saunders, A., de Salas, K., \& Lewis, I. (2016). Augmented Exergaming: Increasing Exercise Duration in Novices. In Proceedings of the 28th Australian Conference on Computer-Human Interaction (OzCHI'16) (542-551). ACM, New York, NY, USA. https://doi.org/10.1145/3010915.3010940

Giannakis, K., Chorianopoulos, K., \& Jaccheri, L. (2013). User Requirements for Gamifying Sports Software. In Proceedings of the 3rd International Workshop on Games and Software Engineering: Engineering Computer Games to Enable Positive, Progressive Change (GAS'13) (22-26). IEEE Press, Piscataway, NJ, USA. https://doi.org/10.1109/GAS.2013.6632585

Goh, D.C.R., Tan, A.C.H., \& Lee, J.S.A. (2017). Gamification of Heel Raise Plantarflexion Physiotherapy. In Proceedings of the 2nd International Workshop on Multimedia for Personal Health and Health Care (MMHealth'17) (35-43). ACM, New York, NY, USA. https://doi.org/10.1145/3132635.3132638

Herpich, M., Rist, T., \& André, E. (2017a). Co-Designing a Recommender System for the Elderly. In Proceedings of the 10th International Conference on PErvasive Technologies Related to Assistive Environments (PETR A'17) (52-55). ACM, New York, NY, USA. https://doi.org/10.1145/3056540.3064948

Herpich, M., Rist, T., \& André, E. (2017b). Towards a Gamified Recommender System for the Elderly. In Proceedings of the 2017 International Conference on Digital Health (DH'17) (211-215). ACM, New York, NY, USA. https://doi.org/10.1145/3079452.3079500 
Hiniker, A., Lee, B., Sobel, K., \& Choe, E.K. (2017). Plan; Play: Supporting Intentional Media Use in Early Childhood. In Proceedings of the 2017 Conference on Interaction Design and Children (IDC'17) (85-95). ACM, New York, NY, USA. https://doi.org/10.1145/3078072.3079752

Huang, L. (2017). Qualitative Analysis of the Application of Self-Determination Theory in Robotics Tournaments. In Proceedings of the Companion of the 2017 ACM/IEEE International Conference on HumanRobot Interaction (HRI'17) (135-136). ACM, New York, NY, USA. https://doi.org/10.1145/3029798.3038342

Johnson, D., Deterding, S., Kuhn, K.A., Staneva, A., Stoyanov, S., \& Hides, L. (2016). Gamification for health and wellbeing: A systematic review of the literature. Internet Interventions, 6, 89-106. http://doi.org/10.1016/j.invent.2016.10.002

Kappen, D.L., Mirza-Babaei, P., \& Nacke, L.E. (2017). Gamification through the Application of Motivational Affordances for Physical Activity Technology. In Proceedings of the Annual Symposium on Computer-Human Interaction in Play (CHI PLAY'17) (5-18). ACM, New York, NY, USA. https://doi.org/10.1145/3116595.3116604

Kosoris, N., Liu, B., Phelps, S.E., Medda, A., Swanson, E., Gore, R.K. et al. (2016). Virtually Transforming DETECT: Moving a 2-D gamified health assessment to Virtual Reality. In Proceedings of the 20th ACM SIGGRAPH Symposium on Interactive 3D Graphics and Games (I3D'16) (207-208). ACM, New York, NY, USA. https://doi.org/10.1145/2856400.2876009

Litovuo, L., Makkonen, H., Aarikka-Stenroos, L., Luhtala, L., \& Makinen, S. (2017). Ecosystem Approach to Medical Game Development: The Relevant Actors, Value Propositions, and Innovation Barriers. In Proceedings of the 21st International Academic Mindtrek Conference (AcademicMindtrek'17) (35-44). ACM, New York, NY, USA. https:// doi.org/10.1145/3131085.3131104

Lumsden, J., Edwards, E.A., Lawrence, N.S., Coyle, D., \& Munafò, M.R. (2016). Gamification of Cognitive Assessment and Cognitive Training: A Systematic Review of Applications and Efficacy. JMIR Serious Games, 4(2), 1. https://doi.org/10.2196/games.5888

Mollee, J.S., Middelweerd, A., Kurvers, R.L., \& Klein M.C.A. (2017). What technological features are used in smartphone apps that promote physical activity? A review and content analysis. Personal Ubiquitous Computing, 21(4), 633-643. https://doi.org/10.1007/s00779-017-1023-3

Nacke, L.E. Klauser, M., \& Prescod, P. (2014). Social player analytics in a Facebook health game. In Proceedings of HCI Korea (HCIK'15) (180-187). Hanbit Media, Inc., South Korea.

Noll, J., Razzak, M.A., \& Beecham, S. (2017). Motivation and Autonomy in Global Software Development: An Empirical Study. In Proceedings of the 21st International Conference on Evaluation and Assessment in Software Engineering (EASE'17) (394-399). ACM, New York, NY, USA. https://doi.org/10.1145/3084226.3084277

Orji, R., Nacke, L.E., \& Marco, C.D. (2017). Towards Personality-driven Persuasive Health Games and Gamified Systems. In Proceedings of the 2017 CHI Conference on Human Factors in Computing Systems (CHI'17) (1015-1027). ACM, New York, NY, USA. https://doi.org/10.1145/3025453.3025577

Pablo, T., Carina, G., Jaime, B., \& Silvia, V. (2016). Enhancing phonological awareness in Children with Dyslexia. In Proceedings of the 4th Workshop on ICTs for improving Patients Rehabilitation Research Techniques (REHAB'16) (121-124), ACM, New York, NY, USA. https://doi.org/10.1145/3051488.3051518

Saksono, H. (2015). Spaceship Launch: Designing a Collaborative Exergame for Families. In Proceedings of the 18th ACM Conference on Computer Supported Cooperative Work; Social Computing (CSCW'15) (1776-1787). ACM, New York, NY, USA. https://doi.org/10.1145/2675133.2675159 
Shameli, A., Althoff, T., Saberi, A., \& Leskovec, J. (2017). How Gamification Affects Physical Activity: Large-scale Analysis of Walking Challenges in a Mobile Application. In Proceedings of the 26th International Conference on World Wide Web Companion (WWW'17 Companion) (455-463). Republic and Canton of Geneva, Switzerland. https://doi.org/10.1145/3041021.3054172

Tondello, G., Orji, R., \& Nacke, L.E. (2017). Recommender Systems for Personalized Gamification. In Proceedings of the 25th Conference on User Modeling, Adaptation and Personalization (UMAP'17) (425-430). ACM, New York, NY, USA. https://doi.org/10.1145/3099023.3099114

Tong, X., Gupta, A., Lo, H. Choo, A., Gromala, D., \& Shaw, C.D. (2017). Chasing Lovely Monsters in the Wild, Exploring Players' Motivation and Play Patterns of Pokémon Go: Go, Gone or Go Away? In Proceedings of the 2017 ACM Conference on Computer Supported Cooperative Work and Social Computing (CSCW'17 Companion) (327-330). ACM, New York, NY, USA. https://doi.org/10.1145/3022198.3026331

Vella, K., Johnson, D., \& Hides, L. (2013). Positively playful: When video games lead to player wellbeing. In Proceedings of the First International Conference on Gameful Design, Research, and Applications (Gamification'13) (99-102). ACM, New York, NY, USA. http://dx.doi.org/10.1145/2583008.2583024

Vourvopoulos, A., Faria, A.L., Ponnam, K., \& Badia, S.B. (2014) RehabCity: design and validation of a cognitive assessment and rehabilitation tool through gamified simulations of activities of daily living. In Proceedings of the 11th Conference on Advances in Computer Entertainment Technology (ACE'14) (Article 26). ACM, New York, NY, USA. https://doi.org/10.1145/2663806.2663852

Werbach, K., \& Hunter, D. (2012). For the Win: How game thinking can revolutionize your business. Wharton Digital Press. Philadelphia.

Zhao, Z., Etemad, S.A., Whitehead, A., \& Arya, A. (2016). Motivational Impacts and Sustainability Analysis of a Wearable-based Gamified Exercise and Fitness System. In Proceedings of the 2016 Annual Symposium on Computer-Human Interaction in Play Companion Extended Abstracts (CHI PLAY Companion'16) (359-365). ACM, New York, NY, USA. https://doi.org/10.1145/2968120.2987726

Zichermann, G., \& Cunningham, C. (2011). Gamification by Design: Implementing Game Mechanics in Web and Mobile Apps. O’Reilly Media.

Published by OmniaScience (www.omniascience.com) Journal of Technology and Science Education, 2019 (www.jotse.org) (C) (i) (8)

Article's contents are provided on an Attribution-Non Commercial 4.0 Creative commons International License. Readers are allowed to copy, distribute and communicate article's contents, provided the author's and JOTSE journal's names are included. It must not be used for commercial purposes. To see the complete licence contents, please visit https://creativecommons.org/licenses/by-nc/4.0/. 